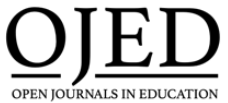

Volume 4, Issue 1 (2021), pp. 97-102 International Journal of

Entrepreneurship and Economic Issues ISSN: 2616-0048 Print/ ISSN: 2631-231X Online

\section{Impact of COVID-19 on Food Security in Nepal}

\author{
Daya Raj Subedi \\ Mid-Western University, Nepal
}

\begin{abstract}
Because of outbreak of the COVID-19, the economic activities have been suspended with the imposition of lockdown in Nepal. There are significant impacts visible in the food security of Nepal. Question remains- how has the COVID-19 pandemic affected the food security in Nepal? The secondary data were used to find the answer to the question.
\end{abstract}

Key Words: Availability, COVID-19, Employment, Food Security, Impact, Lockdown, Nepal

The human infectious disease COVID-19 evolved in Wuhan, China in December 2019 has been spread across more than 200 countries of the world. At some time, more than half of the world's population had been asked or ordered to stay inside the home in order to prevent the human to human transmission of the virus. The COVID-19 does not only have health issue but also has social and economic impact. In this regard, the World Food Programme (WFP) (2020b) predicted around 265 million people in low and middle income countries will face acute food insecurity by the end of 2020 up from 135 million in 2019 because of economic impact of COVID-19. The cases of COVID-19 in Nepal have been rapidly increasing since the first case reported in January 2020. Nepal enforced nationwide lockdown beginning from 24 March 2020. Being low income countries, the considerable number of populations, especially poor and vulnerable group, is prone to suffer from the acute hunger due to the socio-economic impact of pandemic in Nepal. In order to locate the impact of COVID-19 in food 
security of Nepal, it is essential to review how food security is defined in international and national level.

Food security is simply comprehended as regular food availability and access to the food required for human lives. Exploring the widely recognized and systematic connotation, the 1996 World Food Summit (WFS) defines the food security as, "food security exists when all people at all time have physical and economic access to sufficient, safe and nutritious food to meet their dietary needs and food preferences for an active and healthy life" (Committee on World Food Security, 2012, p. 5). Furthermore, Food and Agriculture Organization (FAO), 2006 pointed the four dimensions of food security in WFS definition i.e. availability, access, utilization and stability. At the national level, the clause two of the Right to Food and Food Sovereignty Act (2018) of Nepal defines "Food security means physical and financial access of every person to the food required for the active and healthy human life".

This paper attempts to dig out the rejoinder to a pertinent question"how the COVID-19 pandemic has an effect on food security in Nepal". It basically analyzes the impact of pandemic in two dimensions of food security- availability and access. For the purpose, the data were collected through the secondary sources such as articles, media releases, policy briefs, reports and studies, newspapers and resources from the official websites. Nevertheless, the information was confined to the period between February to May 2020.

\section{Reduced Purchasing Power}

The impact of COVID-19 in Nepalese economy is more palpable. The COVID-19 with subsequent imposition of lockdown has substantially decreased the economic activity causing the job losses and reduced working hours. As per the official government prediction, Nepal will witness the economic growth rate of $2.27 \%$ in the fiscal year of 2020/2021 (Central Bureau of Statistics, 2020). Arts and entertainment, accommodation and food, construction, manufacturing, transport and communication and wholesale and retail trade are the hardly hit employment sectors. Because of, hundreds of thousands of people are facing job loss and vulnerable to job loss. "Between 1.6 and 2.0 million jobs are likely to be disrupted in Nepal in the current crisis, either with complete job loss or reduced working hours and wages" (ILO, 2020. p. 1). Similarly, the rapid assessment of UNDP Nepal shows "it is found that every three in five employee lost their jobs in the micro and small businesses that were surveyed" (UNDP Nepal, 2020, para. 3). Most of the employment sectors remains closed which ultimately affected the remuneration of the employees. The rapid assessment on the problems faced by the workers due to COVID-19 carried out by the General 
Federation of Nepalese Trade Unions (GEFONT) in 323 enterprises across the country shows that " $68.73 \%$ of industrial and service enterprises have been closed" (GFONT, 2020, p. 1). Furthermore, the assessment points out $42.10 \%$ of the enterprises did not pay any salary or remuneration to the workers whereas $31.5 \%$ of the enterprises paid the full wages in the month of 16 March to 15 April (Ibid.).

In recent years, tourism and migration provides attractive employment opportunities as well as significantly contributes to the annual GDP in Nepal. However, the pandemic does not leave both unaffected. "Given the international travel restrictions and fall in discretionary disposable incomes worldwide, tourism receipts in Nepal are projected to fall by $60 \%$ in 2020 resulting in a loss of foreign currency earning worth USD 400 million" (UNDP Nepal para. 2). With regard of migration, 20 to $25 \%$ of Nepali employed in foreign land will lose the jobs because of COVID-19 out of 20 to 30, 00, 000 Nepali in foreign employment (Shrestha, 2020). It is worthy to mention that around $56 \%$ of households regularly receive the remittances in Nepal (Ibid.).

The cumulative effect of job loss reduced working hours and unpaid/partially paid wages, or enumeration has direct or indirect negative consequences on the household income in Nepal. This has ultimately decreased the purchasing power of individual household. More specifically, the reduced purchasing power has definitely curtailed the trouble-free economic access to sufficient, safe, and nutritious food. If the situation persists for longer time, the number of affected population will keep going upward.

\section{Food Availability at Risk}

Extending lockdown has disrupted the food supply chains inside and outside Nepal posing tremendous risks to food availability in Nepal. The market update published in early May shows that "food availability in markets was considered to be insufficient told by $53 \%$ of traders in the assessed districts" (Nepal Food Security Monitoring System, 2020, p. 1). The lockdown imposed within and outside Nepal has caused the closure of borders and disrupted the cross-border transportation services severely affecting the supply of food commodities. Not surprisingly, Nepal is highly dependent on India on importing the food. In the midst of crisis "Indian producers halted rice exports to Nepal in early April" (WFP, 2020a, p. 1). Likewise, the import of vegetables has also been limited. However, the WFP quotes that these circumstances do not cause immediate problems as Nepal has food stock for three months (Ibid.).

At the national level, the pandemic is knocking the door at the time of wheat harvest and beginning of paddy cultivation. There are reports 
coming out from across Nepal illustrating insufficient available of improved seeds as well as manures required for paddy cultivation. For instance, the farmers are facing the problems for the paddy cultivation as the supply of fertilizers and seeds and agricultural implements has been disrupted due to the lockdown in Surkhet district (The Rising Nepal, 2020). This will reduce rice production in the fiscal year of 2020/21 in Nepal which ultimately origins higher dependency on food imports in new normal. In positive note, the problems of labor shortages for the agriculture production have been addressed somehow because of increased reverse migration. Nevertheless, the COVID-19 has severe effect on poultry, milk and vegetable production in Nepal. The closure of markets, disruption of transportation services, lack of access to cold stores and shutdown of hotel and restaurants pushed farmers to destroy the vegetable and dairy products. As of, the farmers from Kapilvastu threw milk on the road while farmers in Nawalparasi and Rupandehi distributed the milk free of cost (Himalayan News Service, 2020). Likewise, the vegetables have been rotten in the agriculture field because of disrupted supply chains causing the loss of investment of farmers in Chitwan district (Poudel, 2020). The loss of investment does have longterm impact in the food production. In essence, the overall national scenario stimulates threats to food availability in the country.

\section{Conclusions}

The COVID-19 has put remarkable pressure in the food security of Nepal through the reduction of the purchasing power as well as the disruption in international as well as domestic food supply chain. However, poor, daily wage labors and vulnerable groups are the frontline victims of the crisis. Having sufficient income savings as well as food stock, the middle class of the society remains unaffected by the food insecurity. The tweet of Nepalese economist elaborates as "Nepal's urban poor and migrant workers are worst affected by the lockdown whilst the middle class with secure source of income and generally stable property prices is not affected and will likely to sustain few more months" (Khanal, 2020). The food supply chains will be eased with the relaxation of the lockdown from the mid-June. Considering the measures of social distancing intact and ongoing health crisis, the more time is needed the supply chains to get into the full shape i.e. possible be until the vaccine is invented to treat the COVID-19. Similarly, the faith of finding a new job and resuming old one will also be the same. Thus, the food security of Nepal, in the absence of appropriate response from the government, will experience the negative effects of pandemic for the longer time. 


\section{REFERENCES}

Committee on World Food Security. (2012). Coming to Terms with Terminology. http://www.fao.org/3/MD776E/MD776E.pdf .

Central Bureau of Statistics. (2020, April 29). Aarthik Barsha 2076/77 ko Rastriya Lekha Tathanka (National Account Statistics of the Fiscal Year 2020/2021). https://cbs.gov.np/wp-content/upLoads/2020/04/CBS-GDPPress-Release-2077-1-17-new.pdf

FAO. (2006, June). Food Security (Policy Brief No. 2). http://www.fao.org/fileadmin/templates/faoitaly/documents/pdf/pdf Food Security Cocept Note.pdf

GEFONT. (2020, May 26). Report on "Rapid Assessment on the Problems Faced by the Workers due to COVID-19. https://www.gefont.org/assets/upload/files/Final\%20GEFONT\%20Rappid \%20Study\%20Report $\% 202077 \% 20$ during $\% 20$ Covid $\% 2019 \% 20($ ENG).pd $\underline{f}$

Himalayan News Services. (2020, April 4). Farmers Forced to Destroy Produce due to Lack of Market. The Himalayan Times. https://thehimalayantimes.com/business/farmers-forced-to-destroyproduce-due-to-lack-of-market/

Khanal, R [@rameshore]. (2020, May 7). After Scrolling down Tens of Miles of Social Network Timelines, I've come to the Conclusions [Tweet]. Twitter. https://twitter.com/rameshore/status/1258355387092393986

ILO. (2020, May 21). COVID-19 Labour Market Impact in Nepal (Briefing Note). https://www.ilo.org/wcmsp5/groups/public/---asia/---ro-bangkok/---ilokathmandu/documents/briefingnote/wcms 745439.pdf

Nepal Food Security Monitoring System. (2020, May 6). Nepal COVID-19: Food Security and Vulnerability 3. https://docs.wfp.org/api/documents/WFP0000115490/download/? ga=2.203669911.660105381.15896854301587278730.1589685430

Poudel, R. (2020, June 8). Barimai Kuhiyera Sakiyo Tarkari, Ani Khulyo Bazaar (The market opens after the vegetable got rotten in the field). Kantipur. https://ekantipur.com/business/2020/06/08/15915926194256713.html

Shrestha, S. K. (2020). COVID-19 Sankat and Samadhan (COVID-19: Crisis and Resolution). Nepal Association of Foreign Employment Agencies. https://rojgarmanch.com/employment/2020/05/12951/

The Right to Food and Food Sovereignty Act, 2075 (2018), Act Number 13 of the year 2075. (2018). http://www.lawcommission.gov.np/en/wpcontent/uploads/2019/07/The-Right-to-Food-and-Food-Sovereignty-Act2075-2018.pdf

The Rising Nepal. (2020, April 23). Farmers Facing the Shortage of Seeds and Fertilizers. The Rising Nepal. https://risingnepaldaily.com/business/farmers-facing-shortage-of-seedsand-fertilisers

UNDP Nepal. (2020, May 26). Three in Five Employee Lost their Jobs due to COVID-19 
https://www.np.undp.org/content/nepal/en/home/presscenter/articles/2020/

Three-in-Five-employees-lost-their-jobs-due-to-COVID19-in-Nepal.html

WFP. (2020a, April 16). Nepal COVID-19: Food Security and Vulnerability Update

2.

https://docs.wfp.org/api/documents/WFP-

0000115489/download/? ga=2.160745914.660105381.1589685430-

1587278730.1589685430

WFP. (2020b, April 21). COVID-19 will Double Number of People Facing Food Crises unless Swift Action is Taken [News Release]. https:/www.wfp.org/news/covid-19-will-double-number-people-facingfood-crises-unless-swift-action-taken

Daya Raj Subedi is an Assistant Professor in the Department of Conflict and Peace Studies, Mid-Western University, Nepal. His major research interests lie in the area of human security, environmental diplomacy, regionalism and multilateralism, South Asian Politics, peace and conflict studies with focus on South Asia, and peace building. Email: dayarajsubedi@gmail.com 